\title{
From global problems to the local action in the Community Garden "AUDZ"
}

\author{
Nora Gavare, Art Academy of Latvia, Latvia
}

\begin{abstract}
The community garden "AUDZ" which is accessible for everyone was created as a local small scale response to the problems of the 21 st century - the depletion of natural resources, air pollution, increase in industrial production, a destructive amount of waste, aging of society, the lack of a sustainable society, etc. Nora Gavare, a designer, participated in the ERASMUS+ international training mobility visit "Development of urban environment" in Hong Cong where she acquired experience and new insights into over-population, rapid growth of urban areas at the expense of the natural habitat and a sharp increase in demand for food products. These trends are not yet evident in Latvia, but they are relevant in the context of the forthcoming climate crisis. At the same time, the demand for healthy locally grown food and zero waste products has increased noticeably. Residents of cities and towns are eager to buy products of known origin, quality and processing factories. However, the only way how to be fully convinced of the quality and "transparency" of the food products is to grow and prepare food stuffs on our own. There are the following questions to be answered: "Do we have enough knowledge how to grow, for example, tomatoes? Haven't people forgotten natural processes while using the advantages of the development of technologies? What would happen if we created PLACES where people could both explore and learn, share and experience?"

As regards such towns in Latvia as Sigulda, where there is a rapid growth of the population and the number of declared residents, it is necessary to promote the creation of the sense of community and education processes due to the lack of the communication opportunities which would promote the interaction of different social groups and enhance the formation of a sustainable society. Such a conclusion was made by performing a photo mapping of Sigulda's public environment in different periods.
\end{abstract}

Keywords: community garden, universal design, sustainable lifestyle

\section{Introduction}

The research of the context of the town and the place, and the needs and habits of residents were conducted in the spring of 2019 in the framework of the master thesis in the study programme of the Latvia Academy of Arts (the supervisor L. Jākobsone), and the project "Community Garden_AUDZ" open to the public focusing on the social, experiential and universal design based on the principles of openness, inclusion and participation was developed. The community garden is not only the place where vegetables are grown but also it is a PLACE to create an understanding of the synergy of human beings, nature and time. The community garden is part of the culture of the future, part of self-sufficiency and responsible living. The garden serves as a meeting and communication place, as well as the bridge between different social groups. The idea of the project " $A U D Z$ ' is to bring the town's residents together and develop gardening in the urban context and thus share and gain knowledge by increasing awareness of the origin of food, as well as promoting the movement of a healthy living and sustainable lifestyle. Fresh and reliable food is a reward for work done, the result of inclusion and participation, care and meaningful activities.

\section{Gardening in the 21st century}

In the last century, the size of land allocated for horticulture and food production in cities has been gradually but steadily decreasing and leaving only scattered small oases in the western big cities. This can be explained by the rapid increase in the value of land and a strong competition, while "new" technologies, such as different types of coolers, have allowed food to be stored for longer periods of time to be fresh and has made it possible to purchase products from long distances. Today, local farmers' products have already become exclusive, they are available in various specialized weekly markets, night markets, off-site retailing and using a direct selling method to meet buyers' growing desire for healthy, seasonal, organic food. In this context it is also important to mention the fact that knowledge and skills about local agricultural processes and products have become a topic for professionals in the field rather than basic information required by general public [1].

In the last decades in the largest European cities, for example, Berlin, Paris, London and others, new food growing movements have returned to the urban environment, where people grow, harvest and consume the produce together. The emphasis is on the word "together" thus the focus is on the lifestyle trends of modern society. It is when people share the place of residence (couch surfing, airbnb etc.), means of transport (Uber, Zipcar, etc), work places / office rooms (co-working), money investments in different projects (kick-starter etc.). This type of sharing economy provides users with lower costs, an opportunity to earn for a service or product provider, 


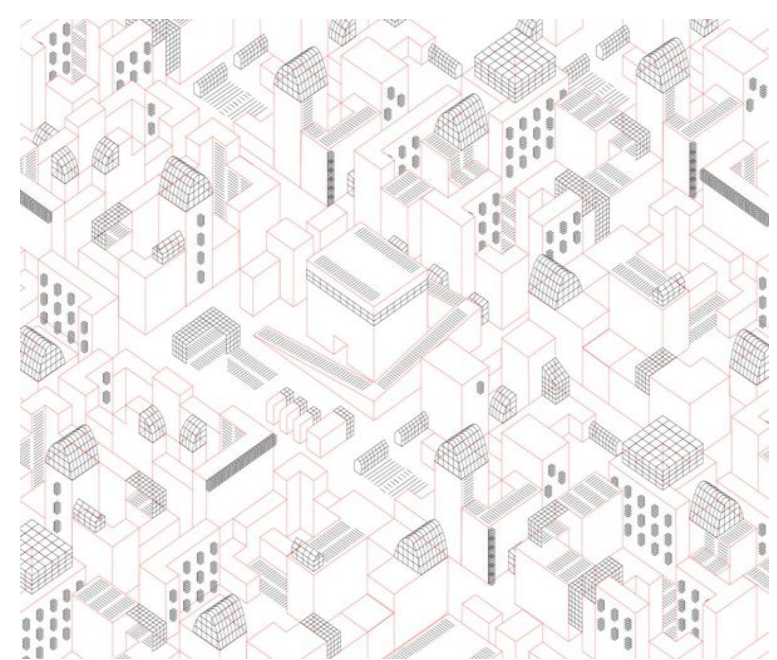

Fig. 1. A utopian (or dystopian?) vision of the future of urban transformation. Greenhouse renaissance

[the author: Nora Gavare, Art Academy of Latvia, critical design, the supervisor: L. Jākobsone]

a range of options and, of course, the strengthening of the community due to a personal, individual attitude. The sharing of the garden

"space" is not the only transformation that corresponds to the trends of modern society. Various local and global movements have emerged, for example, food councils, initiatives of edible-cities, mobile community kitchens, food sharing. Also, in recent years food growing has expanded in an increasing variety of ways: gardening on roofs (it is not a brand new innovation of this century though; the air gardens of Babylon existed for about 600 years B.C.), plant and animal farms on floating platforms (Rotterdam), aquaponics capsule cultivation, vegetable roof gardens, plant skyscrapers in Singapore, mobile farms / markets, miniature farms in small residential areas and many more [2]. These new initiatives clearly indicate the public's desire for "transparent", healthy and understandable food, as well as the desire to create natural places in the context of the urban environment. These new initiatives clearly indicate the society's desire for "transparent", healthy and comprehensive food, as well as the desire to create natural places in the context of the urban environment.

One of the future speculations of the author in the framework of the conceptual design course at Art Academy of Latvia was directly related to the changes in the urban environment by focusing on overpopulation, the huge demand for food and a possible technological apocalypse: the city which has the pattern resembling the greenhouse square glass structures and the linearity of garden furrows in various expressions, greenhouses and gardens as appendices to new and already historic architecture (Fig. 1). It is a kind of the network that describes society and its habits as an overall idea in relation to the concept of the Superstudio about the continuous monument: an architectural model for total urbanization [3].

\section{Community gardens}

If it has been important for European cities to develop the culture of small gardens and promote their revival in recent years, then in Latvia they are still being destroyed - small gardens are being replaced by residential complexes, shopping centres, sports halls, schools, office buildings, parking lots. Although zones of small gardens have often gained a notorious reputation as neglected areas prone to fires, thefts, etc., it may be wiser to improve garden structures by transforming activities and adapting them to modern needs to promote societal sustainability, education and growth.

One of the ways how to transform small gardens is creation of community gardens which act as catalysts. In the context of the community garden, this would be related to the rapid development of the community, promotion of creativity from the project participants and the involvement of people in the processes. It is also important to mention that this kind of transformation of gardens "sows seeds" in the minds of the participants and allows them to be aware of a wide range of growing opportunities in the urban context, sustainability and ecological issues, as well as to prove they can be self-sufficient as a society and influence the environment providing the community with food and be responsible for the environment.

- The type of organization and action may differ among various communities, for example:

- the state and local government financially support such projects with funding from various foundations (for example, the unit of urban agriculture "Agrocite" project in Paris);

- cooperation projects between a local government and a vegetable market (several examples in the Netherlands, including Toetje community garden in Groningen);

- small initiatives to meet the needs of a specific group of people for fresh products (for example, Pluk en Moestuin community garden in Eenrum village in the Netherlands);

- pop-up short-term gardens as part of festivals to draw the public attention (a vivid and successful example was The Union Street Urban Orchard during London Architecture Festival in 2010);

- projects initiated in the public space by individuals or groups of the population with the aim of drawing the public attention (this category would include public community garden in Sigulda town " $A U D Z$ " created in the framework of the master thesis);

- projects involving schools and other institutions, where the community is usually well defined and closed (for example, Ikšķile Free School and permaculture garden attached to it);

- other types of community gardens. 


\section{Involvement of society - public participation}

Community gardens and other food-related activities open to the public often focus on meaningful activities, change and multidimensional processes. Such movements are part of the concept of 'transforming social innovation', which usually results from alterations in mutual development. Moluaert explains social innovation (included in the book by Ciska) with "community action that creates new rules and social relationships to meet the needs of society and lead to social change and opportunity. The focus of social innovation on changing relationships redefines the potential role of residents in society, as well as their ability to improve the living environment based on local needs" [4].

The factor of participation is important in the context of social innovation thus allowing the society to participate in the development and implementation of creative projects and express the opinion which is important to them, thus creating an emotional connection with the project, place and community. In such a participation process there must be a "project manager" or a creator who is an expert in the field and can lead the group work, engage in mutual communication with the participants involved in the process, and creatively promote the brainstorming of non-standard solutions and ideas. In addition, these participants / end-users may not have knowledge or experience in the specific field (in most cases they do not have). Although it poses various risks to the end result, in the context of social design and the creation of place, such a principle can lead to more effective solutions for the user, easier and more convenient identification of the needs, views and aspirations of the specific group of society and target audience.

Participation in the design process distinguishes four important basic elements in the interaction of which this method can be applied: authors / creators, participants / users, projects and cases [5].

Participation is an integral part of social innovation projects, promoting unity and growth in the community, in the process of placemaking (the Latvian translation of the term was suggested by Kīnasts / www.nebetja.eu) and certainly in the context of community garden projects, where community interaction and activities are vital for a successful outcome.

The place and environment can act as a catalyst. Careful and inclusive planning, the creation of usercentred design highlight and improve the synergies between people and nature (in the garden context), the environments they create in addition to the communication among people and between people and the community at countless levels.

Meiss has identified three design strategies to assist a sense of identity for people (included in the book by Carmona) by creating places for people or their groups:
- "Environments responsive to, and based on designer's deep understanding of the values and behaviour of the people and groups concerned and the environmental features crucial to their identity;

- participation of future users in the design of their environment;

- environments that users can modify and adapt thus letting users to participate in "the design of environment" (Matthew Carmona, Steve Tiesdell, Tim Heath, Taner Oc. Public places urban spaces. The dimensions of urban design. New York: Routhledge, 2003. pp. 121-123).

The community garden " $A U D Z$ " is a social project which is based on the principle of public participation and it covers all stages of the project from generating ideas, creating structures and procuring seedlings to maintaining the garden, organizing activities and participating in them (Fig. 2, 3, 4, 5). In fact, all groups and generations of society are actively involved in the project. Participation in this case refers to creative collaboration in the design process between the designer or the author and users. Participation not only promotes the emotional connection with the project, the formation of a sense of community and place, but also initiates the process of knowledge and experience transfer. In addition, the involvement of residents makes it possible to create a result that is appropriate for the given community.

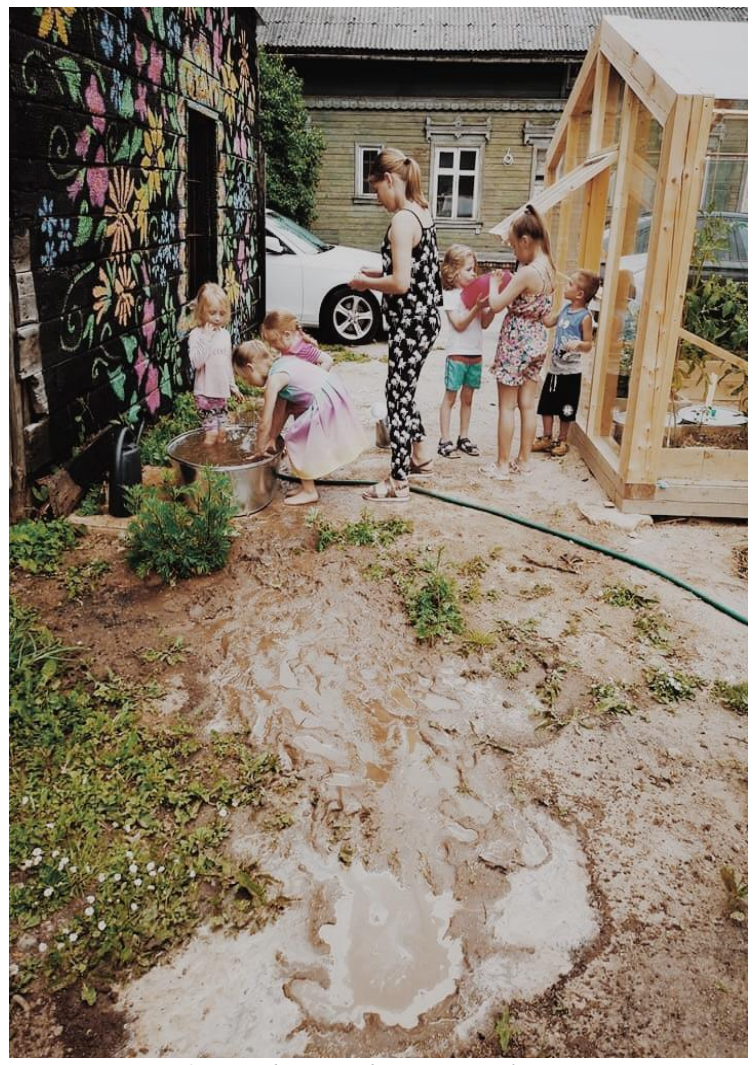

Fig. 2. Residents and visitors in the process [photo Nora Gavare, 2019] 


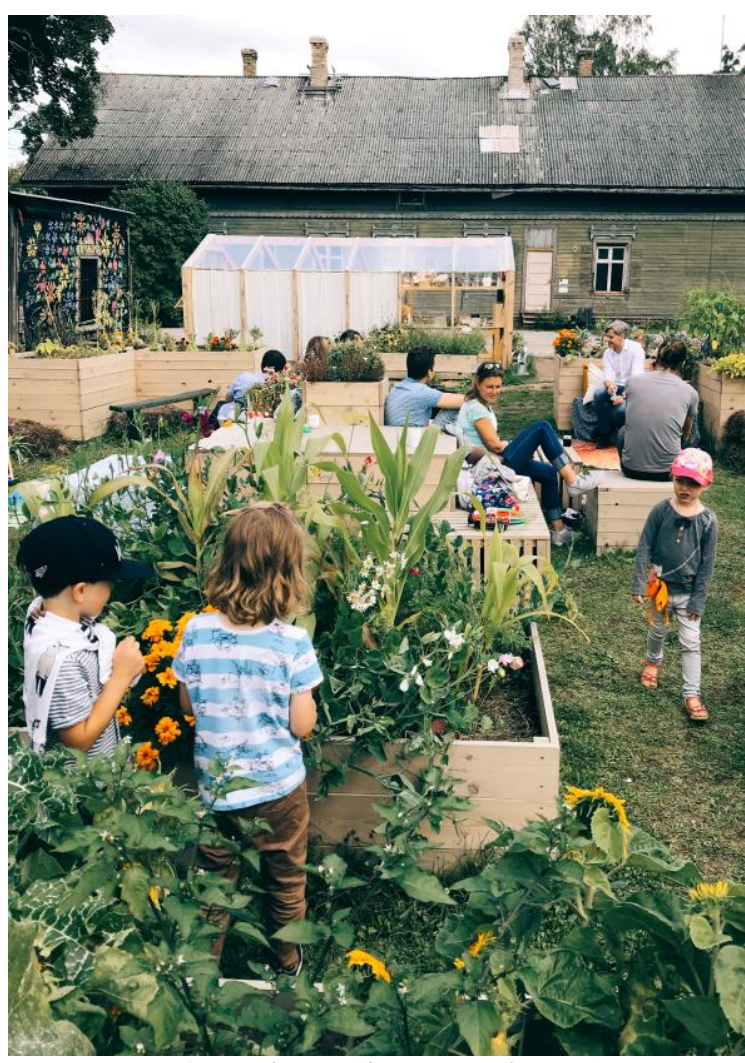

Fig. 3. Residents and visitors in the process [photo Nora Gavare, 2019]

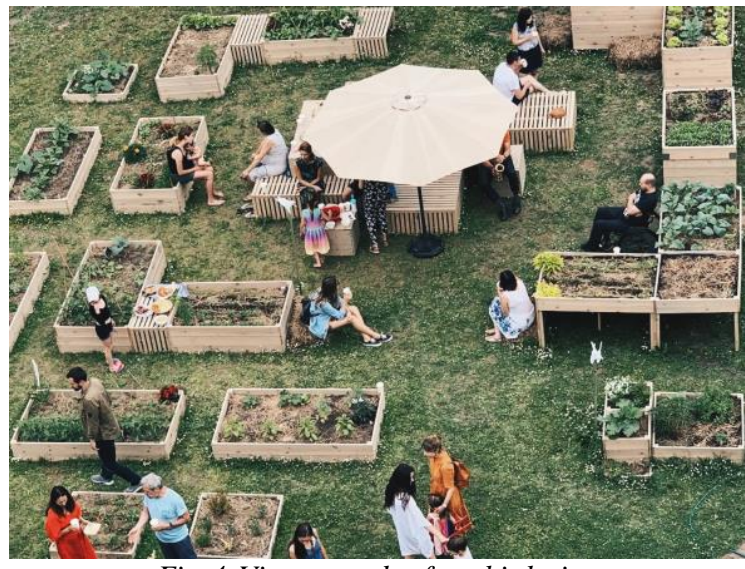

Fig. 4. View to garden from birth view [photo Nora Gavare, 2019]

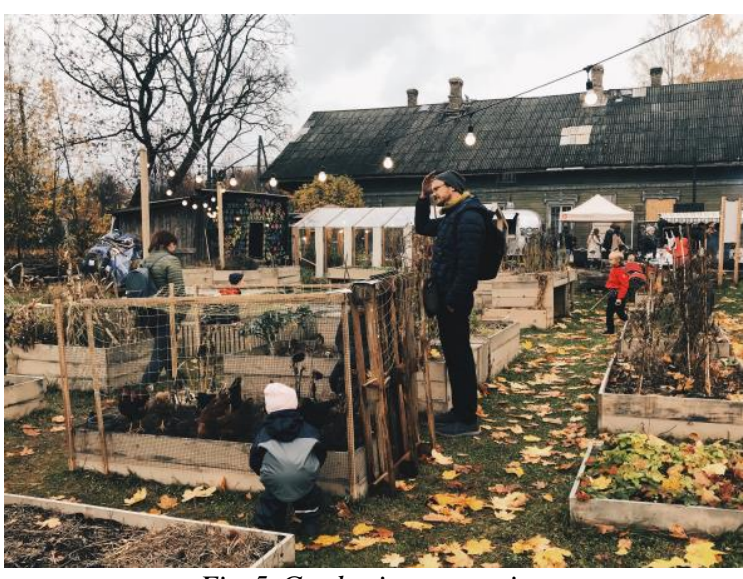

Fig. 5. Garden in autumn time [photo Nora Gavare, 2019]
The scale of participation may be varied: 1) small-scale public involvement - starting with giving advice, bringing inspiration books or seedlings; 2) medium-scale public involvement occasional visits, participation in creative workshops, involvement in making of structures, involvement in garden work processes, environmental testing, etc.; 3) large-scale public involvement - regular visits and participation in almost all activities, cooperation with non-governmental organizations, institutions funded by local government and educational institutions.

The beginning stage of the garden development was arranged in cooperation with Sigulda Pensioneers' Association and organization "Cerību spārni" (in English: Wings of Hope) of young people with special needs, students of Sigulda Art School and State Gymnasium, as well as local residents and garden visitors. Together they created a vision of the idea of a garden today, its role in society, what functions it should perform, and created conceptual garden plans with a game method. Local residents actively participated in the workshops for making garden structures on site, while Sigulda State Gymnasium students created module elements according to the given drawings during the home economics lessons, thus students had the opportunity to develop objects designed for a real purpose to be located in the real urban environment and used by real users.

\section{Spatial planning and accessibility}

The most important factors in the garden planning (Fig. 6) have been the availability of the environment and the promotion of mutual communication among visitors. By providing access to the plant beds' arrangement from all sides, the environment provides scenarios for many people to be active in one place and encourages

mutual interaction. In addition, multi-functional communication zone in the centre of the garden which is a structure of asymmetrical shape is meant for recreation, reading, resting, playing table games, having picnics, incidental meetings with other visitors or for using the platform as a stage for performances of one - two artists or master classes.

The garden " $A U D Z$ ' is divided into zones where structures are gradually raised in height (Fig. 7) with plant bed arrangements which are $15 \mathrm{~cm}$ high in the left side of the garden and gradually raised with each next line reaching $90 \mathrm{~cm}$ (the rise continues up to the greenhouse and historic Villa Green architectural spaces). Therefore it is possible to grow various plants with different depths of root systems and provide more convenient access to the garden for different generations of visitors and people with different functional abilities. Thus each person instinctively goes in the direction of the area in the garden where it is more comfortable for him /her to work by choosing to squat, sit or stand. 
Fig. 6. Cross-section. Gradual rise of the garden structures [the author of the diagramme: Nora Gavare]

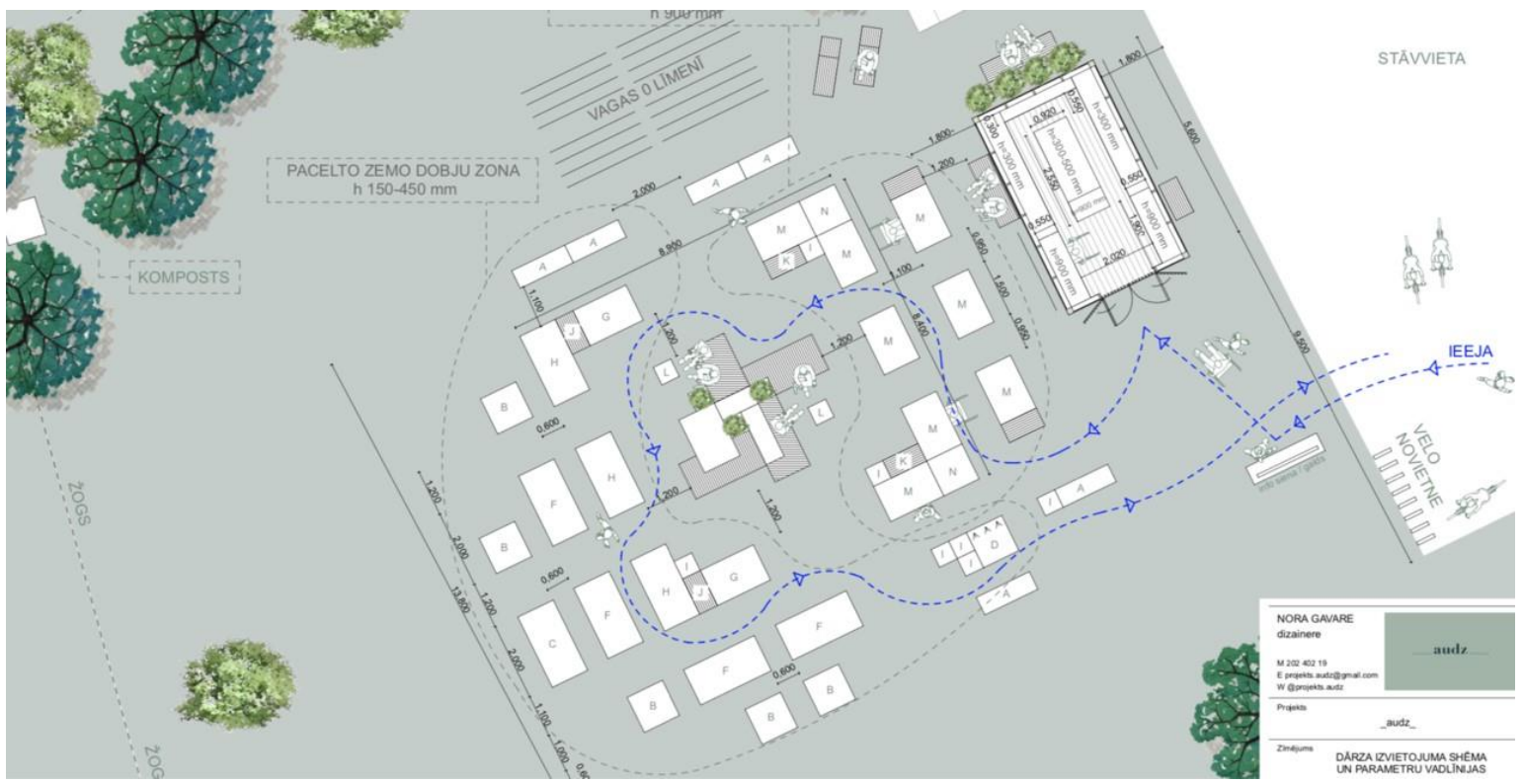

Fig. 7. Community garden "AUDZ” general plan [the author of the general plan: Nora Gavare]

The greenhouse and plant beds have been located closer to the parking lot and the hard surface, so that wheelchair users would need to go as little distance as possible to the area available to them.

\section{The action model}

The garden should have a clear scheme of activities so that visitors can easily navigate the gardening work and activities in the garden (Fig. 8). The continued involvement of volunteers is certainly a challenge as well. If there is an intense public involvement in a project, the focus is on the factor of responsibility: who is responsible for what and when. Therefore it is important to define the task and the operation framework of the project.

In order to reduce the confusion that most visitors experience in an unusual environment, the garden has signs with invitations to specific activities. The signs, in a sense, reflect the thoughts and desires of plants, as if reviving them and allowing them to speak, for example, «Water me!», «Look at me closer!», «Remove weeds around me!», «Taste me!». Such exclamation sentences encourage exploration, investigation and create new experience using elements of a game. The signs are required to put in a special bowl "The completed work".

The action model of the community garden " $A U D Z$ ' is characterized by the following directions:

- a social form of new collective action;

- common visions which support and highlight the value of food grown by participants;

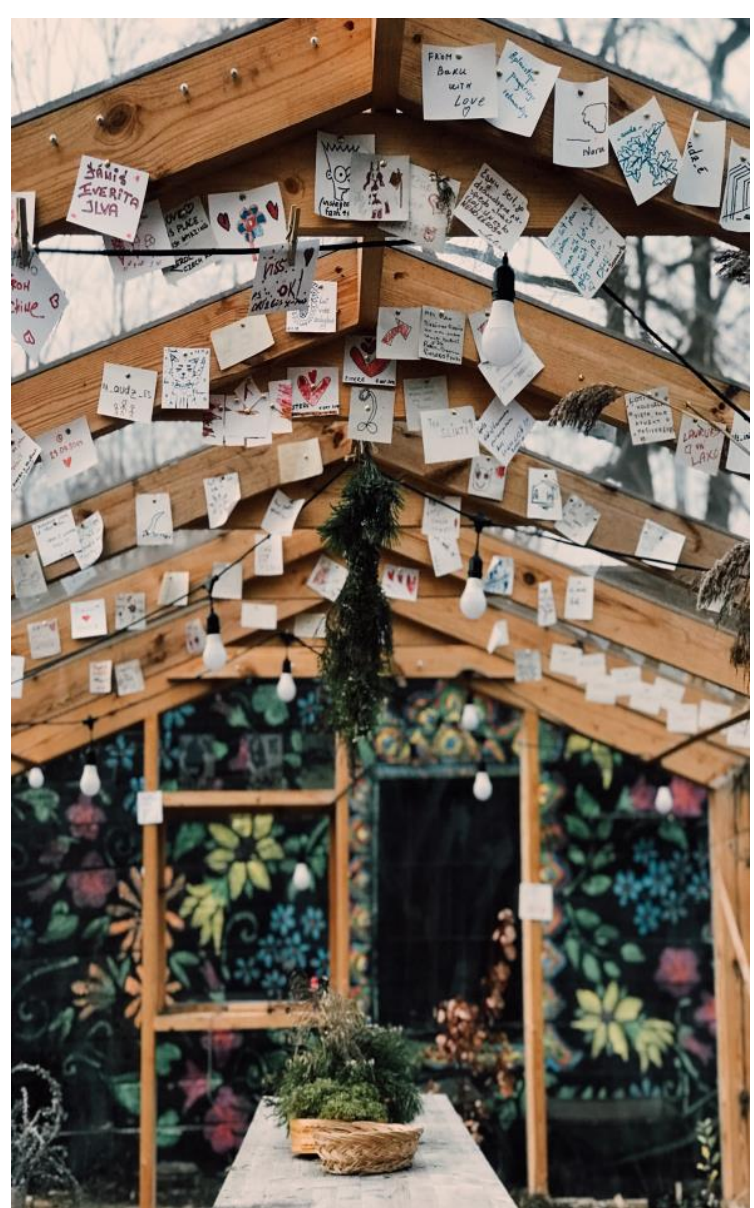

Fig. 8. Specific activities in the garden [photo Nora Gavare, 2019] 
- self-organised mutual support network which is mostly based on the local community;

- experimental forms of food growing;

- experimental forms of societal growth;

- bonds of trust and identity that create the capacity for social cooperation;

- inclusion and participation of society.

The focus of the community garden is mainly on the growth and interaction of society, which include awareness of problems, education, skills development, participation, mutual communication and encouragement for proactive action. To achieve this, the garden includes several functions - not only the cultivation, care and harvesting of crops, but also various educational thematic events, concerts, talks, community picnics, the exchange of books / and information centre in the greenhouse, markets of local producers / farmers and their organic products and other activities.

\section{Conclusions}

The community garden is open not only to a particular community, but also to the general public: local residents and visitors from other cities or abroad are welcome by providing everyone with the opportunity to participate in its creation, growth or experience.

In a sense, the community garden ' $A U D Z$ ' is like a test or a mirror of society to identify its ability to share, to care, to work for a larger group of people and to increase the level of well-being of society as well as individuals. It actively promoted the horticultural movement in Latvia and acted as a catalyst and inspiration for other urban gardening projects.

The project has become internationally recognized and it has received the International Universal Design Expert Award 2020 in Munich and a certificate of the recognition in the competition in Vienna "International Information Design Award 2020”.

\section{References}

1. Kropp, C. Urban Food Movements and Their Transformative Capacities. The International Journal of Sociology of Agriculture \& Food 24.3 (2018): 413-430.

2. The Guardian [online 10.12.2020.]. https://www.theguardian.com/sustainable-business/2014/jul/02/next-gen-urbanfarms-10-innovative-projects-from-around-the-world

3. Superstudio [online 10.12.2020.].http://arch122superstudio.blogspot.com/2012/06/continuous-monument-architectur al-model_15.html

4. Ciska, U., Luminna, G.H. Connecting resourcefulness and social innovation: exploring conditions and processes in community gardens in the Netherlands. Local Environment. The International Journal of Justice and Sustainability (2018): 147

5. Huybrechts, L. Participation is Risky. Approaches to Joint Creative Processes. Amsterdam: valiz , 2014.

\section{AUTHOR:}

Nora Gavare, mag. art., urban community garden _audz_author (2018), senior interior designer at NŌR interjeri (since 2015). In recent years, increased attention has been paid not only to human-friendly and suitable interior solutions, but also to the issues of creating a humane urban environment and devloping sustainable living conditions and communities. Studied functional design in Art Academy of Latvia and urban design in Hong Kong Polytechnic University School of Design. E-mail: nora.gavare@gmail.com

Kopsavilkums. Kopienas dārzs „AUDZ” ir atvērts ne tikai konkrētai kopienai, bet arī visai sabiedrībai - gan vietējai, gan viesiem no citām pilsētām vai ārvalstīm, rodot iespēju katram piedalīties tā veidošanā, izaugsmē vai pieredzes radī̌̌anā. „AUDZ” savā zin̄ā ir kā sabiedrības tests jeb spogulis, lai apzinātu tās spēju dalīties, rūpēties, darboties lielākas cilvēku grupas labā un vairot sabiedrības, kā arī indivīdu labsajūtas līmeni. Tas ir aktīvāk virzījis dārzkopības kustību Latvijā un bijis kā katalizators un iedvesmas avots citiem pilsētvides dārzniecības projektiem.

Projekts ir guvis starptautisku ievērību un saṇēmis International Universal Design Expert Award 2020 Minhenē un atzinību International Information Design Award 2020 konkursā Vīnē. 